J. Pijar MIPA, Vol. VIII No.1, Maret : 7 - 10

ISSN 1907-1744

\title{
KORELASI ANTARA UMUR INKUBASI DENGAN TAHAP PERKEMBANGAN EMBRIO Chelonia mydas YANG DIINKBASI PADASUHU INKUBASI YANG BERBEDA
}

\author{
Syamsul Bahri \\ Program Studi Pendidikan Biologi FKIP Universitas Mataram \\ Email: syamsulsalihu@yahoo.com
}

\begin{abstract}
Abstrak : Kecepatan perkembangan embrio Chelonia mydas dipengaruhi oleh suhu inkubasi. Embrio yang diinkubasi pada suhu $31 \pm 1^{\circ} \mathrm{C}$ (SF) mencapai tahap 17 pada umur inkubasi 22-23 hari, tahap 19 pada umur inkubasi 26 hari, dan tahap 22 pada umur inkubasi 31 hari. Embrio yang diinkubasi pada suhu $26 \pm 1{ }^{\circ} \mathrm{C}(\mathrm{SM})$ mencapai tahap tahap 17 pada umur inkubasi 39-40 hari, tahap 19 pada umur inkubasi. 45 hari, dan tahap 22 pada umur inkubasi 52-53 hari. Hasil pengamatan terhadap struktur histologis gonad embrio menunjukkan bahwa gonad embrio tahap 17, 19, dan tahap 22 telah berupa gonad indiferen. Gonad-gonad pada tahap tersebut sudah dapat dibedakan menjadi bagian korteks dan bagian medula. Bagian korteks berupa epitel selapis silindris, sedangkan bagian medula mengandung jaringan ikat dan kelompok-kelompok sel. Bakal sel kelamin ditemukan pada bagian medula dan korteks. Dengan demikian dapat disimpulkan bahwa periode TSP Chelonia mydas yang diinkubasi pada suhu $31 \pm 1^{\circ} \mathrm{C}(\mathrm{SF})$ terentang dari umur inkubasi 22 hari hingga umur inkubasi 31 hari, sedangkan periode TSP Chelonia mydas yang diinkubasi pada suhu $26 \pm 1{ }^{\circ} \mathrm{C}(\mathrm{SF})$ terentang dari umur inkubasi 39 hari hingga umur inkubasi 53 hari.
\end{abstract}

Kata kunci: Chelonia mydas, TSP, umur inkubasi, suhu feminisasi, suhu maskulinisasi

\begin{abstract}
Embryonic development Rate of Chelonia mydas is affected by incubation temperature . The embryos were incubated at $31 \pm 1{ }^{\circ} \mathrm{C}(\mathrm{FT})$ reached embryonic stage of $17^{\text {th }}$ at $22-23^{\text {rd }}$ of incubation day, embryonic stage of $19^{\text {th }}$ at $26^{\text {th }}$ of incubation day, and embryonic stage of $22^{\text {nd }}$ at $31^{\text {st }}$ of incubation day. The embryos were incubated at $26 \pm 1{ }^{\circ} \mathrm{C}(\mathrm{MT})$ reached embryonic stage $17^{\text {th }}$ at $39-40^{\text {th }}$ incubation day, embryonic stage $19^{\text {th }}$ at $45^{\text {th }}$ day of incubation , and embryonic stage $22^{\text {nd }}$ at $52-53^{\text {rd }}$ incubation day Observations on the histological structure of the gonadal embryos showed that the embryonic gonad stages $17^{\text {th }}, 19^{\text {th }}$, and $22^{\text {nd }}$ have been in indifferent stage. Gonads at this stage can be distinguished in two parts, cortex and medulla. Cortex as a layer of cylindrical epithelium, while the medulla consist of connective tissue and groups of cell. Primordial Germ Cells are found both in medulla and cortex . It can be concluded that the TSP of Chelonia mydas were incubated at $31 \pm 1{ }^{\circ} \mathrm{C}$ ( FT ) extended from $22^{\text {nd }}$ of incubation day until the $31^{\mathrm{st}}$ of incubation day, whereas the TSP of Chelonia mydas were incubated at $26 \pm 1{ }^{\circ} \mathrm{C}(\mathrm{MT})$ extended from $39^{\text {th }}$ of incubation day until the $53^{\text {rd }}$ of incubation day.
\end{abstract}

Keywords : Chelonia mydas, TSP, feminization temperature, maskulinization temperature

\section{PENDAHULUAN}

Tahap perkembangan embrio hewan-hewan ovipar sangat terkait dengan suhu dan umur inkubasi, karena kecepatan pembelahan sel-sel embrional merupakan fungsi dari laju sintesis senyawa-senyawa dan organelorganel sel yang akan diparuh saat mitosis berlangsung. Pada hewan-hewan TSD, tahapan perkembangan embrionya memiliki periode yang peka suhu yang kemudian dikenal sebagai periode termosensitif (TSP, Thermosensitive Period). Pada periode ini suhu inkubasi diduga sangat berperan menentukan arah perkembangan gonad. Beberapa penelitian menunjukkan bahwa perlakuan suhu tinggi pada periode TSP mengarahkan perkembangan gonad indifferen menjadi ovarium, sedangkan perlakuan suhu rendah menyebabkan gonad indifferen berkembang menjadi testis. Chelonia mydas yang merupakan salah satu jenis hewan TSD juga menunjukkan respon yang serupa ketika diberi perlakuan suhu pada periode TSP. Penentuan periode TSP pada hewan TSD sangat penting dilakukan untuk memastikan bahwa perlakuan suhu inkubasi diberikan pada umur inkubasi yang tepat.

Hingga saat ini, penentuan periode TSP pada Chelonia mydas belum dilakukan . Penelitianpenelitian yang dilakukan pada Chelonia mydas dengan menggunakan perlakuan suhu inkubasi lebih banyak didasarkan pada umur inkubasi yang biasa dilakukan oleh peneliti lain yang menggunakan Trachemys scripta, Dermochelyx coriaceae, dan spesies-spesies TSD lainnya. Suhu feminisasi (suhu inkubasi yang menyebabkan $100 \%$ telur berkembang menjadi betina) pada Trachemys scripta misalnya, adalah $30^{\circ} \mathrm{C}$. Pada suhu tersebut, periode TSP diyakini terjadi pada embrio tahap 
17 hingga embrio tahap 22 yang jatuh pada umur inkubasi 17 hari hingga 28 hari. Pada embrio tahap 17, struktur histologis gonad indiferen mulai berdiferensiasi [1]. Meskipun demikian, suhu feminisasi Chelonia mydas lebih tinggi dari suhu feminisasi Trachemys scripta yaitu $31^{\circ} \mathrm{C}$ [2]. Perbedaan suhu tersebut tentu akan mempengaruhi kecepatan perkembangan embrio sehingga akan berdampak pada bergesernya window TSP. Oleh karena itu penentuan periode TSP pada Chelonia mydas dengan mengamati struktur histologis gonad embrio yang diinkubasi pada suhu feminisasi menjadi penting untuk dilakukan.

\section{METODE PENELITIAN}

\section{Embrio Chelonia mydas}

Kompleks adrenal-gonad-ginjal yang menjadi bahan utama penelitian ini diisolasi dari embrio Chelonia mydas yang diinkubasi pada suhu tertentu. Telur-telur sumber adrenal-gonad-ginjal ini diperoleh dari telur yang baru dioviposisikan di lokasi peteluran penyu Pantai Pangumbahan Sukabumi Selatan, Jawa Barat. Telurtelur tersebut dibawa ke Laboratorium Analisis Struktur dan Perkembangan SITH, ITB, tempat pemberian perlakuan. Selama dalam perjalanan, telur-telur tersebut ditempatkan dalam kemasan khusus (carrier box) yang berisi pasir laut lembab untuk mempertahankan kelembaban telur sepanjang perjalanan. Telur-telur selanjutnya dipindahkan ke dalam baskom plastik berisi pasir laut basah hingga telur-telur tertimbun didalamnya.

Telur-telur diinkubasi di dalam inkubator (Blue M) pada suhu $31^{\circ} \mathrm{C} \pm 1^{\circ} \mathrm{C}$ (suhu feminisasi, SF), atau disimpan di dalam ruang berpendingin suhu $26^{\circ} \mathrm{C} \pm 1{ }^{\circ} \mathrm{C}$ (suhu maskulinisasi, SM). Pasir laut disiram dengan air ledeng setiap 2 atau 3 hari sekali agar telur tidak kering selama proses inkubasi berlangsung. .

\section{Pembuatan Sayatan Histologis Gonad}

Embrio pada umur-umur inkubasi tertentu dikeluarkan dari telur kemudian difoto dengan menggunakan kamera digital. Setelah itu, kompleks adrenal-gonad-ginjal diisolasi dari embrio tahap perkembangan 17, 19 dan 22 [3]. Embrio yang diinkubasi pada suhu feminisasi hingga tahap 17 disebut SF17, sedangkan embrio yang diinkubasi pada suhu maskulinisasi hingga tahap 17 disebut SM17. Kompleks adrenal-gonad-ginjal embrio Chelonia mydas pada berbagai tahap perkembangan difiksasi dalam larutan Bouin selama 24 jam, kemudian didehidrasi dengan alkohol berseri dan NBA dan diinfiltrasi menggunakan parafin (titik leleh $56^{\circ} \mathrm{C}-58^{\circ} \mathrm{C}$ ). Kompleks organ tersebut kemudian ditanam dalam kotak kertas berisi parafin cair. Organ disayat dengan mikrotom putar (American Optical) secara melintang dengan ketebalan $8 \mu \mathrm{m}$. Pita sayatan ditempel di atas kaca objek menggunakan albumen Meyer kemudian dilakukan pewarnaan Hematoxylin - Eosin. Hasil sayatan diamati di bawah mikroskop Nikon Eclipse TE 300, kemudian difoto menggunakan kamera digital Nikon DXM $1200 \mathrm{~F}$.

\section{HASIL DAN PEMBAHASAN}

\section{Morfologi dan Struktur Histologis Gonad Embrio Chelonia mydas Tahap Perkembangan 17 hingga Tahap Perkembangan 22}

Tahap perkembangan embrio Chelonia mydas yang diinkubasi pada SF dan SM ditentukan berdasarkan persamaan ciri morfologinya dengan ciri morfologi embrio Trachemys scripta. Gambar morfologi embrio pada tahap perkembangan 17, 19, dan tahap 22 serta struktur histologis gonadnya disajikan pada Gambar 1.

Morfologi embrio Chelonia mydas tahap 17 yang berukuran sekitar $4,0 \mathrm{~cm}$. memiliki caruncle berupa benjolan putih pada permukaan anterior rahang atas, dan tepi tunas anggotanya sudah tampak mulai bergerigi. Pada embrio tahap 19 yang berukuran sekitar 4,2 cm, semua sisik karapaks dan plastron tampak dengan jelas dan mulai berpigmen. Pada embrio tahap 22 yang berukuran sekitar $4,5 \mathrm{~cm}$, pigmentasi bagian kepala, sisik dan anggota gerak semakin bertambah.

Hasil pengamatan terhadap struktur histologis gonad embrio menunjukkan bahwa gonad embrio tahap 17, 19, dan tahap 22 berupa gonad indiferen. Gonad-gonad pada tahap tersebut sudah dapat dibedakan menjadi bagian korteks dan bagian medula. Bagian korteks berupa epitel selapis silindris, sedangkan bagian medula mengandung jaringan ikat dan kelompok-kelompok sel. Bakal sel kelamin ditemukan pada bagian medula dan korteks. Kondisi gonad pada tahap-tahap tersebut mirip dengan gonad tahap indiferen yang ditemukan oleh Barlian [4] dengan metode inkubasi yang berbeda.

Untuk mencapai tahap perkembangan yang sama, embrio yang diinkubasi pada SM memerlukan jumlah hari inkubasi yang lebih banyak dibandingkan dengan embrio yang diinkubasi pada SF. Embrio yang diinkubasi pada suhu $31 \pm 1^{\circ} \mathrm{C}(\mathrm{SF})$ mencapai tahap 17 pada umur inkubasi 22-23 hari, tahap 19 pada umur inkubasi 26 hari, dan tahap 22 pada umur inkubasi 31 hari. Embrio yang diinkubasi pada suhu $26 \pm 1^{\circ} \mathrm{C}(\mathrm{SM})$ mencapai tahap tahap 17 pada umur inkubasi 39-40 hari, tahap 19 pada umur inkubasi. 45 hari, dan tahap 22 pada umur inkubasi 52-53 hari.

Dengan demikian semakin tinggi suhu inkubasi embrio semakin tinggi kecepatan pertumbuhannya. Secara umum, peningkatan suhu akan diikuti dengan peningkatan kecepatan metabolisme sel [5] melalui peningkatan kecepatan reaksi molekul-molekul yang terlibat dalam pembentukan energi [6]. Korelasi antara umur (hari) inkubasi dengan tahap perkembangan embrio Chelonia mydas disajikan pada Gambar 2. 


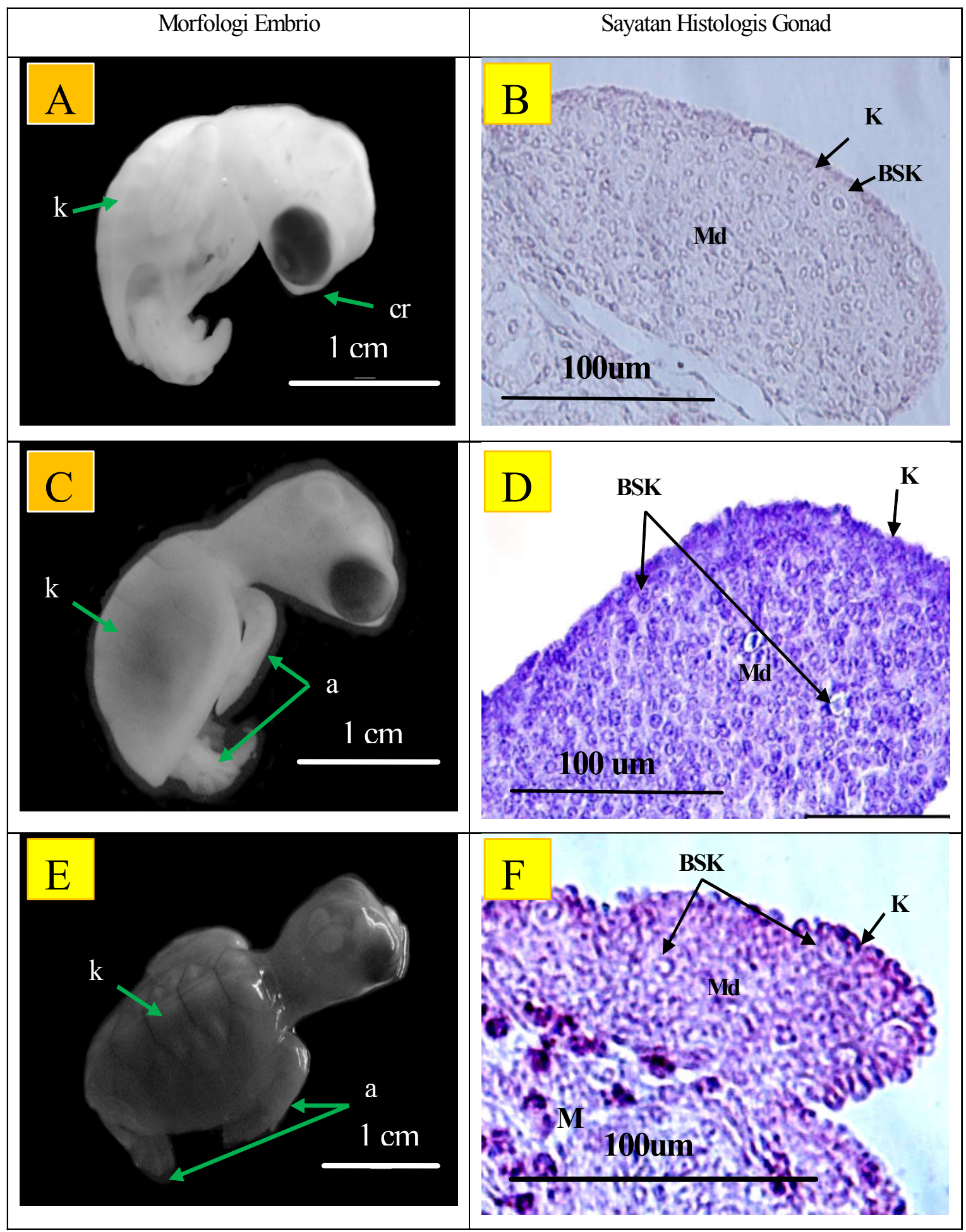

Gambar 1 Morfologi dan struktur histologis gonad embrio tahap perkembangan 17 (A dan B), 19 (C dan D), dan tahap 22 (E dan F). a, anggota gerak; BSK, bakal sel kelamin; cr, caruncle; K, korteks gonad; Md, medula gonad; $\mathrm{M}$, mesonefros; $\mathrm{k}$, karapaks. 


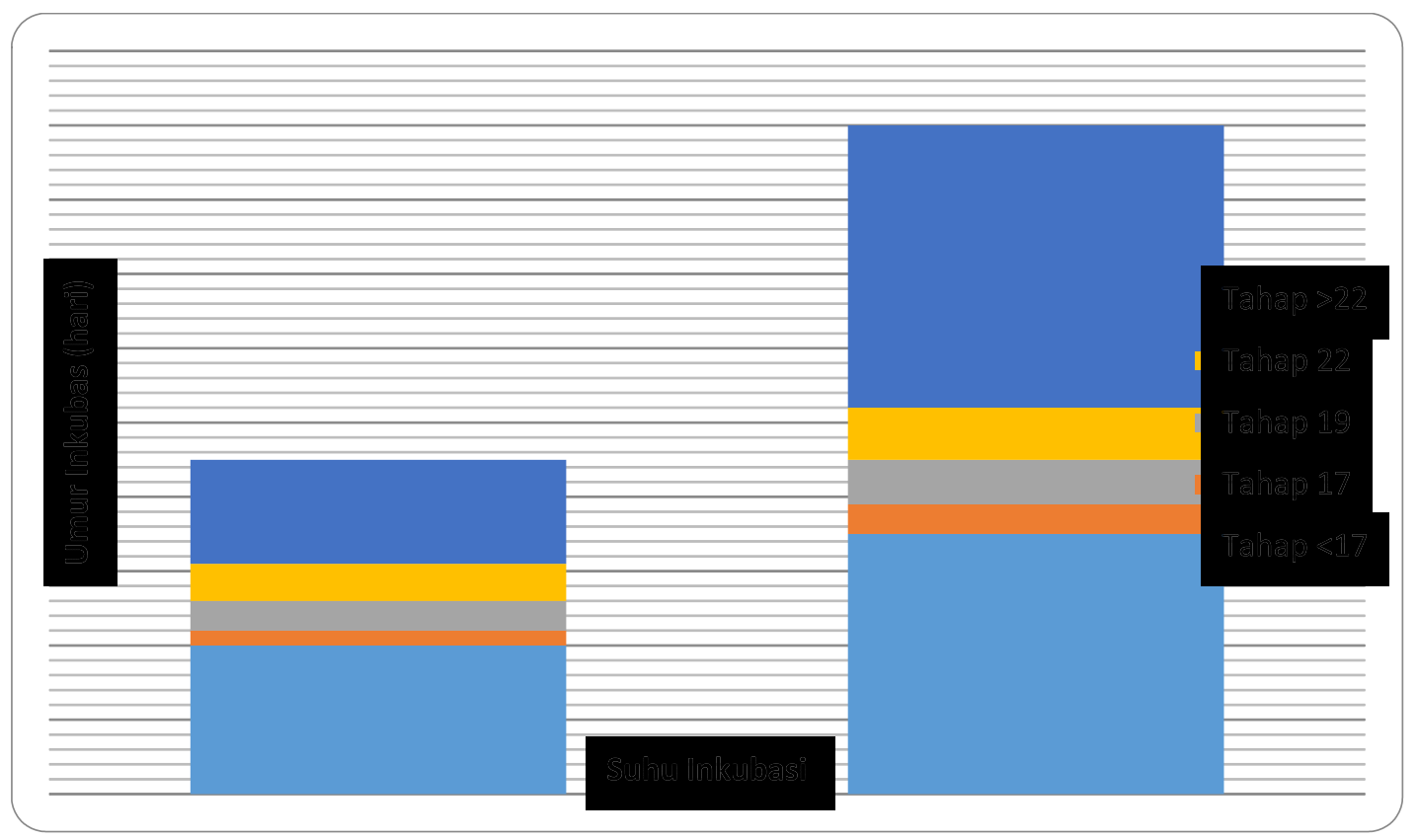

Gambar 2 Korelasi antara umur (hari) inkubasi dengan tahap perkembangan embrio Chelonia mydas yang diinkubasi pada suhu $31 \pm 1^{\circ} \mathrm{C}$ (Suhu Feminisasi, SF) atau suhu $26 \pm 1^{\circ} \mathrm{C}$ (Suhu Maskulinisasi, SM).

\section{KESIMPULAN}

Periode TSP Chelonia mydas yang diinkubasi pada suhu $31 \pm 1{ }^{\circ} \mathrm{C}(\mathrm{SF})$ terentang dari umur inkubasi 22 hari hingga umur inkubasi 31 hari, sedangkan periode TSP Chelonia mydas yang diinkubasi pada suhu $26 \pm 1{ }^{\circ} \mathrm{C}(\mathrm{SF})$ terentang dari umur inkubasi 39 hari hingga umur inkubasi 53 hari.

\section{DAFTAR PUSTAKA}

[1] Desvages, G., Girondot, M., dan Pieau, C. (1993): Sensitive stages for the effects of temperature on gonadal aromataseactivity in embryos of the marine turtle Dermochelys coriacea, Gen.Comp.Endocrinol., 92,54-61

[2] Mustika, I. (1987): Diferensiasi gonad betina dan jantan embrio penyu hijau (Chelonia mydas) yang diinkubasi pada suhu tinggi dan rendah, Tesis Sarjana Biologi, Institut Teknologi Bandung, Bandung

[3] Greenbaum, E. (2002): A standardized series of embryonic stages for the emydid turtle Trachemys scripta, Can.J. Zool., 80, 1350-1370

[4] Barlian, A. (1999): Determinasi dan diferensiasi seks gonad embrio penyu hijau (Chelonia mydas) yang diinkubasi pada suhu feminisasi dan suhu maskulinisasi, Disertasi ITB

[5] Clark, A. (2004): Is there a universal temperature dependence of metabolism, J.Anim. Ecol., 18, 2, 252-256
[6] Gillooly, F., Brown, J.H., West, G.B., Savage, V.M., Charnov, E.L. (2001): Effects of Size and Temperature on Metabolic Rate, Science, 293, 2248-2251 